\title{
Recent advances in understanding and managing
}

\section{diverticulitis [version 1; peer review: 3 approved]}

\section{Carola Severi (D1, Marilia Carabotti², Alessia Cicenia¹, Lucia Pallotta1, Bruno Annibale ${ }^{2}$}

\begin{abstract}
${ }^{1}$ Department of Internal Medicine and Medical Specialties, University Sapienza of Rome, Viale del Policlinico 155, 00161 Rome, Italy 2Medical-Surgical Department of Clinical Sciences and Translational Medicine, University Hospital S. Andrea, University Sapienza of Rome, Via di Grottarossa 1035-1039, 00189 Roma, Italy
\end{abstract}

V1 First published: 29 Jun 2018, 7(F1000 Faculty Rev):971

https://doi.org/10.12688/f1000research.14299.1

Latest published: 29 Jun 2018, 7(F1000 Faculty Rev):971

https://doi.org/10.12688/f1000research.14299.1

\section{Abstract}

In the past few decades, the increasing socioeconomic burden of acute diverticulitis (AD) has become evident, and with the growth of the population age, this significant economic impact will likely continue to rise. Furthermore, recent evidence showed an increased rate of hospital admissions especially evident among women and younger individuals. The natural history and pathophysiology of this clinical condition is still to be fully defined, and efforts continue to be made in the identification of risk factors and the establishment of relative preventive strategies. The actual therapeutic strategies aimed to modulate gut microbiota, such as rifaximin or probiotics, or to reduce mucosal inflammation, such as mesalazine, present a relatively poor efficacy for both the prevention of the first AD episode (primary prevention) and its recurrence (secondary prevention). In the last few years, the main goal achieved has been in the management of $A D$ in that uncomplicated AD can, to a larger extent, be managed in an outpatient setting with no or little supportive therapy, a strategy that will certainly impact on the health costs of this disease. The problem of $A D$ recurrence remains a topic of debate.

The aim of this review is to present updated evidence on $A D$ epidemiology and relative open clinical questions and to analyze in detail predisposing and protective factors with an attempt to integrate their possible modes of action into the several pathogenic mechanisms that have been suggested to contribute to this multifactorial disease. A unifying hypothesis dealing with the colonic luminal and extra-luminal microenvironments separately is provided. Finally, evidence-based changes in therapeutic management will be summarized. Because of an ascertained multifactorial pathogenesis of uncomplicated and complicated AD, it is probable that a single 'causa prima' will not be identifiable, and a better stratification of patients could allow one to pursue tailored therapeutic algorithm strategies.

\section{Open Peer Review}

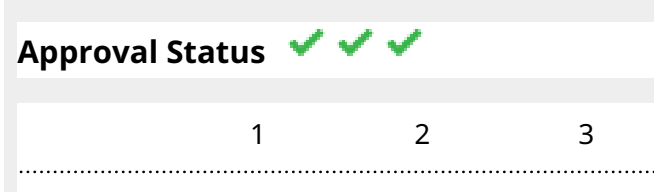

version 1

29 Jun 2018

Faculty Reviews are review articles written by the prestigious Members of Faculty Opinions. The articles are commissioned and peer reviewed before publication to ensure that the final, published version is comprehensive and accessible. The reviewers who approved the final version are listed with their names and affiliations.

\section{Andreas D Rink, Leverkusen General Hospital, Leverkusen, Germany}

2. Massimo Bellini, University of Pisa, Pisa, Italy

3. Angel Lanas, University Hospital, Zaragoza, Spain

Any comments on the article can be found at the end of the article. 


\section{Keywords}

Diverticulitis, Risk factors, Prevention, Therapy, Diet, Microbiota,

Colonic muscle, Drugs

Corresponding author: Carola Severi (carola.severi@uniroma1.it)

Author roles: Severi C: Conceptualization, Funding Acquisition, Writing - Original Draft Preparation; Carabotti M: Conceptualization, Writing - Original Draft Preparation; Cicenia A: Investigation; Pallotta L: Investigation; Annibale B: Writing - Review \& Editing

Competing interests: No competing interests were disclosed.

Grant information: Carola Severi receives funding from the University Sapienza of Rome, 000324_17_RS_SEVERI_SAPIENZA_PROGETTI 2016. The funders had no role in decision to publish, or preparation of the manuscript.

The funders had no role in study design, data collection and analysis, decision to publish, or preparation of the manuscript.

Copyright: ( $) 2018$ Severi C et al. This is an open access article distributed under the terms of the Creative Commons Attribution License, which permits unrestricted use, distribution, and reproduction in any medium, provided the original work is properly cited.

How to cite this article: Severi C, Carabotti M, Cicenia A et al. Recent advances in understanding and managing diverticulitis [version 1; peer review: 3 approved] F1000Research 2018, 7(F1000 Faculty Rev):971 https://doi.org/10.12688/f1000research.14299.1

First published: 29 Jun 2018, 7(F1000 Faculty Rev):971 https://doi.org/10.12688/f1000research.14299.1 


\section{Introduction}

Colonic diverticula, sac-like herniations of the colonic mucosa and submucosa through the muscle layers, represent a common gastrointestinal condition in the Western world with a prevalence that grows with age, from less than $10 \%$ in people younger than 40 years of age to $50-66 \%$ after 80 years of age ${ }^{1,2}$. While most people with colonic diverticula remain asymptomatic, making diverticulosis not a disease per se, around $20 \%$ of patients will develop diverticular disease (DD) when they experience abdominal symptoms (i.e. symptomatic uncomplicated DD [SUDD]) and $1-4 \%$ will develop acute diverticulitis (AD) ${ }^{3}$. The natural history and pathophysiology of this clinical condition are still under definition. Clinical scenarios of DD and its natural history have been recently summarized ${ }^{4}$. In the past few decades, the increasing socioeconomic burden of DD has become evident, and efforts have been made to identify risk factors to establish relative preventive strategies and to achieve more standardized treatment approaches.

The aim of this review is to present updated evidence on $\mathrm{AD}$ epidemiology and relative open clinical questions and to analyze in detail predisposing and protective factors with the attempt to integrate their possible modes of action into the several pathogenic mechanisms that have been suggested to contribute to this multifactorial disease. Finally, evidence-based changes in therapeutic management will be summarized.

\section{The clinical problem and its impact on health costs}

$\mathrm{AD}$ is an inflammatory process that involves one or more colonic diverticula, often associated with pericolonic inflammation that is classified as uncomplicated or complicated, the latter being characterized by the presence of abscesses, fistulas, peritonitis, and colonic stenosis. Complications most commonly occur with the first episode of $\mathrm{AD}^{5}$. $\mathrm{AD}$ clinical classification is mainly based on the use of modified Hinchey's criteria derived from contrast-enhanced computerized tomography (CT) imaging ${ }^{6}$ or on the more recent German guidelines ${ }^{7}$. However, an important role in $\mathrm{AD}$ diagnosis is also covered by abdominal ultrasound (US), which, in the hands of experienced investigators, can be used as a sensitive and specific diagnostic technique, limiting the use of $\mathrm{CT}$ after negative or inconclusive abdominal US $^{7-10}$.

Recent epidemiological studies have confirmed the increase of hospital admissions for $\mathrm{AD}$ in recent years ${ }^{11}$. A previous epidemiological analysis, carried out in the USA in $2012^{12}$, showed that diverticulitis was the third most-common gastrointestinal diagnosis from hospital admission and the leading indication for elective colon resection, with an increase of $41 \%$ from 2000 and an estimated cost of 2.6 billion dollars per year. A more recent analysis showed that the national cost of diverticulitisrelated emergency department visits in the USA, from 2006 to 2013 , increased by $105 \%{ }^{13}$. Similarly, a recent observational analysis based on real-world data from an Italian region reported that direct healthcare costs for episodes of diverticulitis from 2008-2014 amounted to approximately 11.4 million euros, of which $95.5 \%$ was for hospitalizations ${ }^{14}$. With the growth of the population age, this significant economic burden is likely to continue to rise.
Currently, the increased rate of hospital admissions is especially evident among women and younger individuals ${ }^{5,15}$. Gender differences are age related in that hospital admissions for AD are predominant in men among subjects younger than 45 years of age, the opposite being true at older ages ${ }^{11}$. Besides, even if older patients display the highest rate of hospital admissions for $\mathrm{AD}$, the increased rate of hospitalization is entirely accounted for by the younger cohorts of patients ${ }^{13}$.

\section{Open clinical questions}

Recent randomized controlled trials (RCTs) confirmed, and national guidelines recommended, that patients with uncomplicated $\mathrm{AD}$ are eligible for outpatient treatment without the use of systemic antibiotics, which should be used in complicated patients instead ${ }^{16-19}$. This conservative management strategy, if adopted, could positively influence the relative economic burden on health costs. However, the problem of AD recurrence remains a topic of debate.

In a recent retrospective population-based cohort study of 65,162 patients identified with a first episode of $\mathrm{AD}$, the rate of hospital admission for recurrence was $11.2 \%{ }^{20}$, lower than was previously reported ${ }^{21}$. This recurrence rate was greater in younger people and women ${ }^{5}$. Generally, the first episode is the most severe, with only $2 \%$ of recurrences resulting in a complicated case. Surgical treatment does not prevent the risk of recurrence, the rate of which is around $15 \%{ }^{22,23}$.

Also, AD seems to predispose patients to developing longterm chronic nonspecific abdominal symptoms, similar to those observed in post-infectious irritable bowel syndrome ${ }^{24}$, with a higher prevalence after severe $\mathrm{AD}^{25}$. The proportion of patients that develop chronic abdominal pain after $\mathrm{AD}$ seems to be influenced by the type of treatment of the first episode, with a lower prevalence after elective laparoscopy (11\%) compared to conservative treatment $(39 \%)^{26}$.

As for now, the underlying mechanisms and risk factors that contribute to $\mathrm{AD}$ and its recurrence still need to be clarified. The actual therapeutic strategies aimed to modulate gut microbiota, such as rifaximin or probiotics, or to reduce mucosal inflammation, such as mesalazine, present a relatively poor efficacy for the prevention of the first $\mathrm{AD}$ episode (primary prevention) and its recurrence (secondary prevention) (see later). A definite assessment of AD-predisposing or -protective factors and these relative mechanisms could greatly contribute to patients receiving the best strategy for prevention, further reducing health costs, and improving the management of DD.

\section{Risk factors for acute diverticulitis and relative recurrence}

The identification of risk factors for $\mathrm{AD}$ has been the scope of several studies for the past few decades. In the last few years, the main concern has been to clarify whether or not factors associated with the first episode are also involved in AD recurrence $^{27}$. Predisposing and protective factors for $\mathrm{AD}$ are summarized in Table 1. Among anthropometric features, obesity has been confirmed to be a risk factor for $\mathrm{AD}$ by a populationbased cohort study $^{28}$ and a recent systematic review and 
Table 1. Summary of predisposing and protective factors associated with primary and secondary prevention of acute diverticulitis.

\begin{tabular}{|c|c|c|c|}
\hline Predisposing & Protective & Need to be confirmed & Irrelevant \\
\hline $\begin{array}{l}\text { ANTHROPOMETRIC AND ANATOMIC FEATURES } \\
\text { - BMI } \\
\text { - waist circumference } \\
\text { - waist-hip ratio } \\
\text { - pancolic diverticula } \\
\text { LIFESTYLE } \\
\text { - smoking } \\
\text { DIET } \\
\text { - red meat intake } \\
\text { DRUGS } \\
\text { - aspirin } \\
\text { - NSAIDs } \\
\text { - corticosteroids } \\
\text { - opioids }\end{array}$ & $\begin{array}{l}\text { LIFESTYLE } \\
\text { - vigorous physical activity } \\
\text { DIET } \\
\text { - high-fiber intake } \\
\text { DRUGS } \\
\text { - statins } \\
\text { OTHERS } \\
\text { - increased vitamin D levels }\end{array}$ & $\begin{array}{l}\text { - alcohol } \\
\text { - younger age } \\
\text { - female gender > } 50 \text { years old } \\
\text { - genetic factors } \\
\text { - family history } \\
\text { - TFNSF15 polymorphisms } \\
\text { - LAMB4 variants } \\
\text { - calcium antagonists } \\
\text { - comorbidities: } \\
\text { - cardiovascular diseases } \\
\text { - chronic obstructive pulmonary disease } \\
\text { - end-stage renal disease }\end{array}$ & $\begin{array}{l}\text { DIET } \\
\text { - nuts } \\
\text { - popcorn } \\
\text { - corn } \\
\text { - fine or coarse grains } \\
\text { - coffee }\end{array}$ \\
\hline
\end{tabular}

BMI, body mass index; NSAIDs, non-steroidal anti-inflammatory drugs

meta-analysis of prospective studies ${ }^{29}$, a risk previously reported in men in whom waist-to-hip ratio was also associated with the risk of diverticular complications ${ }^{30}$. As far as smoking is concerned, a lifestyle risk factor already known to be associated with $\mathrm{AD}$, recent evidence showed that it further represents an increased risk of developing complicated $\mathrm{AD}^{31,32}$ and requiring surgery ${ }^{33}$. Red meat intake, particularly of unprocessed meat, was identified as the main dietary risk factor for diverticulitis in a prospective Health Professionals Follow-Up Study (1986-2012) of 46,461 men ${ }^{34}$.

A systematic review and meta-analysis ${ }^{35}$ confirmed that nonsteroidal anti-inflammatory drugs (NSAIDs), which are already known to be risk factors for $\mathrm{AD}^{36}$ and perforation ${ }^{37}$, as well as steroids and opioids, presented an increased odds ratio for perforation and abscess formation.

Among protective factors, vigorous physical activity, as was previously reported ${ }^{38}$, was confirmed by a recent meta-analysis to be inversely related to diverticulitis ${ }^{29}$ but not by a populationbased cohort study ${ }^{28}$. As far as diet is concerned, no recent further evidence is available on the lower risk of hospitalization for $\mathrm{AD}$ with a vegetarian diet and a high intake of dietary fibers ${ }^{39,40}$. Instead, statins, which have already been associated with a reduced risk of perforation ${ }^{35,37}$, have also been recently reported to be associated with a reduced risk of emergency surgery ${ }^{41}$. Finally, vitamin D serum levels, which when high pre-diagnostically have been associated with a low risk of AD among patients with diverticulosis ${ }^{42}$, have been related to the severity of DD endoscopic appearance ${ }^{43}$.

Some known risk factors still need to be confirmed. Evidence regarding alcohol consumption and DD are discordant, with some studies showing a positive association ${ }^{44,45}$ and others not ${ }^{46}$.
Regarding drugs, the potential protective effect of calcium channel blockers in reducing the rate of diverticular complications observed in case-control analyses ${ }^{37,47}$ needs to be confirmed. Also, the recent epidemiological evidence that reports a higher prevalence of $\mathrm{AD}$ among women older than 50 years of age ${ }^{11,48}$, younger individuals $s^{5,11,13}$, and patients with end-stage renal disease $^{49}$, as well as the association of cardiovascular disease and chronic obstructive pulmonary disease with complicated $\mathrm{DD}^{28,50}$, needs to be confirmed and explained.

Finally, recent studies corroborate the previous observation of a strong familial aggregation both in diverticulosis and in diverticular complications, suggesting a role for genetic factors ${ }^{51}$. A relationship has been reported between complicated diverticulitis and a single nuclear polymorphism in the TFNSF15 gene, a T-cell maturation receptor gene associated with other colonic inflammatory diseases ${ }^{52}$, and between early onset diverticulitis or unrelated sporadic diverticulitis and variants in the laminin $\beta 4$ gene (LAMB4), which codes for constituents of the extracellular matrix that regulate the function of the enteric nervous system $^{53}$.

Of note, even if clinicians frequently advised patients to avoid some foods, such as nuts, corn, and popcorn, these are not associated with an increased risk of diverticulitis ${ }^{54}$, and the same is true for fine or coarse grains ${ }^{28}$. Regarding the possible role of coffee, a previous study did not report any association between coffee use and $\mathrm{DD}^{44}$, similar to a recent cross-sectional study that did not observe any significant difference between coffee drinking and diverticulosis compared to SUDD or previous diverticulitis ${ }^{55}$.

An assessment of risk factors associated with recurrent AD is on its way, even if more studies are required to better target secondary prevention. Currently, increased risks of recurrent 
$\mathrm{AD}$, obtained with a logistic regression model, have been shown to be younger age, female sex, smoking, obesity, a Charlson comorbidity index score of more than 20, dyslipidemia, and first complicated $\mathrm{AD}^{20}$. Other risks of recurrence are primary diverticulitis with abscess formation, an inflamed segment of more than $5 \mathrm{~cm}$, multiple diverticula, and diverticula throughout the colon, with the risk of subsequent diverticulitis more than doubled after two earlier episodes of diverticulitis that further increases for every episode of recurrence ${ }^{56}$.

\section{Pathophysiology and possible underlying biological mechanisms}

A unifying hypothesis to integrate the diverse risk factors and their contribution to the pathophysiology of AD has not yet been put forward. The current hypothesis asserts that the susceptibility of diverticula to inflammation is explained by local ischemia, retained stool, stercoral mucosal trauma by fecaliths, and diverticular wall distension that facilitates microperforations and favors bacterial translocation ${ }^{57}$. Inflammation and infections can spread transmurally (peridiverticulitis), ending in different types of $\mathrm{AD}$ complications. The improvement of the clinical outcome of the disease obtained with antibiotics supports an involvement of bacteria in most $\mathrm{AD}$ complications. A dual inflammatory-infective contribution might then be considered in $\mathrm{AD}$ pathogenesis ${ }^{58,59}$ with likely different interconnections if considering the luminal colonic and the extra-luminal microenvironments (Figure 1).
The luminal microenvironment is dominated by microbiota that has been suggested to play an important role in the pathogenesis of the disease ${ }^{60}$. In uncomplicated DD, recent evidence indicates the presence of dysbiosis whose principal feature is the depletion of bacterial species with anti-inflammatory activity $^{61}$ that likely favors mucosal inflammation. Recently, in rodent models, it has also been reported that aging-associated microbiota promotes inflammation and intestinal permeability and increases pro-inflammatory cytokines in the blood ${ }^{62}$, an aspect that could be relevant in DD, whose prevalence increases with age. Diet has an essential role in the maintenance of a healthy microbiota, and several types of food have been reported to be risk factors for $\mathrm{AD}$ likely through changes in microbiota composition. Among them, unprocessed red meat affects cecal microbial composition and metabolites ${ }^{63}$ and aggravates experimental-induced colitis, an effect counteracted by the co-consumption of resistant starch, which is considered a type of fiber that provides the benefits of both insoluble and soluble fibers ${ }^{64}$, an observation that could fit with the protective effects of a high-fiber intake in AD prevention. Fiber is known to possess anti-inflammatory effects and to have a eubiotic impact on gut microbiota $^{65,66}$.

The presence of mucosal inflammation is still a matter of debate, except for DD-associated segmental colitis, a very rare mucosal inflammation sparing the rectum ${ }^{67}$. Evidence derived from studies carried out on small numbers of patients supports

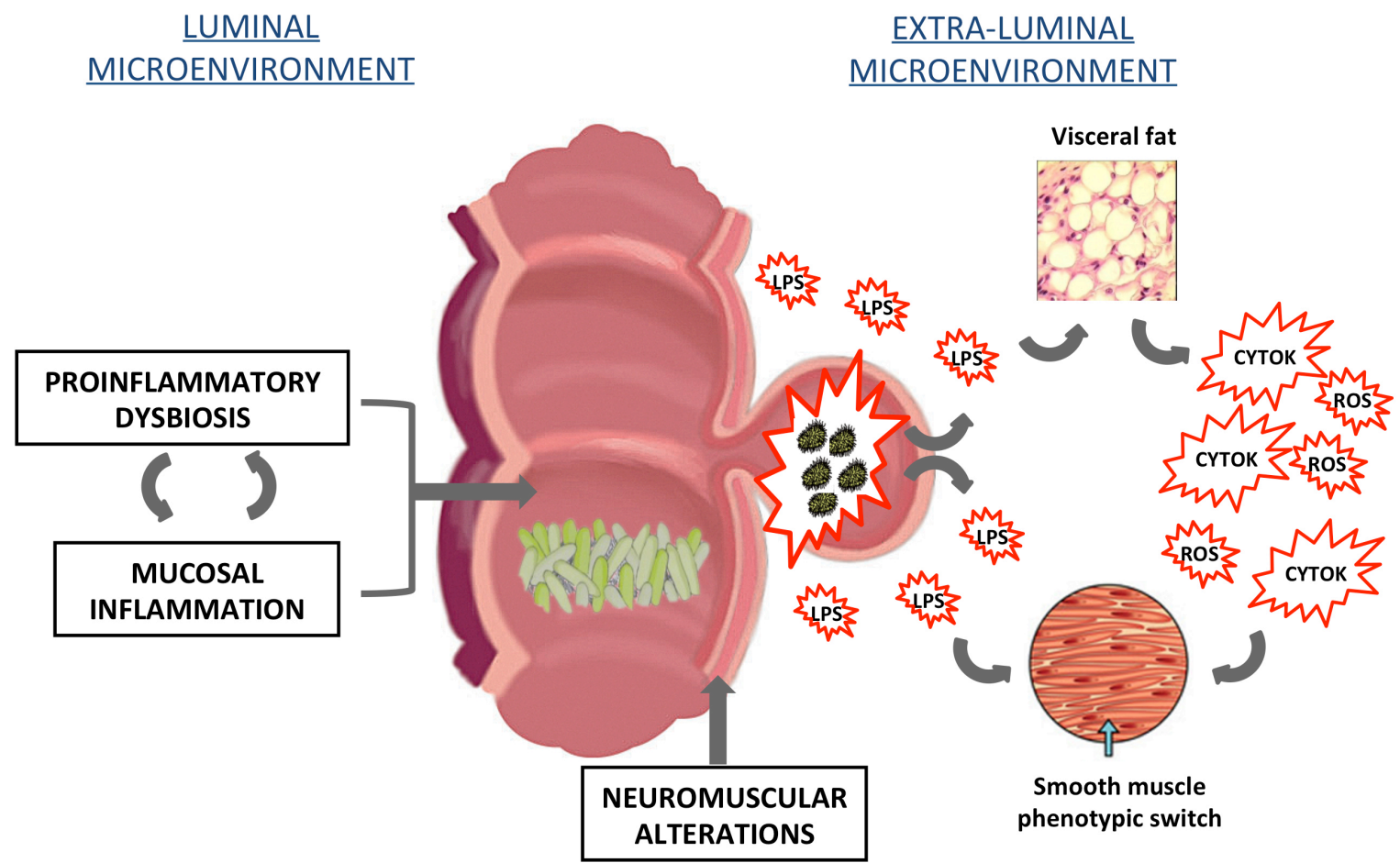

(c) LAURA CARABOTTI

Figure 1. Pathogenic unifying hypothesis. CYT, cytokines; LPS, lipopolysaccharide; ROS, reactive oxygen species. 
its presence. A strong positive correlation has been reported between activated $\mathrm{CD} 68^{+} / \mathrm{CD} 163^{+}$macrophages and complicated sigmoid diverticulitis ${ }^{68}$, and an increase in the mast cell population has been found in the mucosal peridiverticular region ${ }^{61}$. iNOS and NO release, which are expressed in an inflammatory context, are increased in colonic mucosa, presenting a progressive trend from diverticulosis to SUDD with previous diverticulitis ${ }^{69}$. Similarly, higher chronic inflammatory infiltrates and inflammatory cytokine expression have been found in the affected tissue in patients after severe versus non-severe diverticulitis ${ }^{25}$. However, the presence of mucosal inflammation has not been confirmed by a recent study carried out in a large number (255) of patients, at least neither in diverticulosis nor in $\mathrm{SUDD}^{70}$. The absence of clear evidence regarding the efficacy of mesalazine in preventing both $\mathrm{AD}$ and its recurrence fits with these discrepancies.

The confirmation of an inflammatory mucosal context has several implications. Firstly, inflamed microenvironment in the gut drives bacterial dysbiosis ${ }^{71}$, favoring a vicious cycle between dysbiosis-driven inflammation and inflammation-driven dysbiosis. Secondly, mucosal inflammation and dysbiosis might lead to dysmotility $^{72}$, another pathogenic factor associated with DD.

Dysmotility is present in both uncomplicated and complicated DD owing to a summation of different abnormalities ${ }^{73}$. Increased motility index and abnormal propulsive activity have been reported in patients with $\mathrm{DD}^{74}$, and enhanced contractile response has been observed in DD muscle strips, with upregulation of substance $\mathrm{P}$ and muscarinic $\mathrm{M}_{3}$ receptors ${ }^{75-77}$. In addition, specific abnormalities in longitudinal muscle relaxation and contents of neural nitric oxide and elastin have been reported ${ }^{78}$, confirming old observations of elastosis confined to the longitudinal muscle layer with subsequent shortening of the teniae coli $^{79}$. A remodeling of the neuromuscular apparatus occurs in complicated DD, consisting of a muscular hypertrophy and architecture disarrangement with reduced content in density of myocytes and contractile myofilaments ${ }^{80}$, an enteric neuropathy with hypoganglionosis, an imbalance in neurotransmitters, a deficiency of glial neurotrophic factors coupled to a nerve fiber remodeling ${ }^{81-83}$, and an increase in collagen deposition in the colon wall ${ }^{84}$. An increase in collagen expression has been observed in human colonic circular and longitudinal smooth muscle cells from complicated DD, parallel to a switch from a contractile to a synthetic phenotype ${ }^{85}$. Of note is also that young patients with $\mathrm{AD}$ present an altered ratio between collagen subtypes with respect to female and older patients ${ }^{86}$.

As a whole, these alterations increase the rigidity and thickening of the colonic wall and subsequent loss of tensile strength that could squeeze the diverticulum orifice, favoring ischemia and stasis. The presence of a hypercontractile status may offer an explanation for the protective role reported for calcium channel blockers and conversely the increased risk of $\mathrm{AD}$ associated with opioids and NSAIDs. Opioids inhibit propulsive motility patterns $^{87}$, while NSAIDs, by inhibition of COX enzymes, reduce prostaglandin-driven vasodilatation and muscle relaxation ${ }^{88}$. Of note, however, is that most of the available data have been obtained from surgical specimens of chronic stages of DD, and then it remains to be established whether neuromuscular alterations correspond to a primary or secondary post-inflammatory event. If the enteric neuromuscular pathology reflects a primary event, this could lead to disturbed intestinal motility patterns, increased intraluminal pressure, and ultimately to the formation of diverticula and relative inflammation, whereas if inflammatory events are considered as the driving force for the neuromuscular abnormalities, these changes would arise as secondary lesions resembling an associated pathology.

The scarce efficacy of the actual medical treatments aimed to counteract luminal pathogenetic factors, however, suggests that some other extra-luminal factors likely contribute to DD complex pathogenesis. Up to now, minor attention has been given to the alterations of the extra-luminal microenvironment. Microbiota-driven mucosal inflammation can favor the translocation of luminal bacteria from the diverticula wall to the perivisceral area with potential activation of receptors of the innate immune system, Toll-like receptors (TLRs), that can drive an inflammatory response in the surrounding tissues. In Crohn's disease, the creeping fat surrounding the affected area was found to contribute to the overall inflammatory response ${ }^{89}$ and to be associated with a structuring/fistulizing course of disease ${ }^{90}$. Similarly, surrounding visceral fat has been hypothesized to play a pathogenic role in complicated $\mathrm{DD}^{91}$. In this context, the clinically significant link that has recently been reported between visceral fat and the severity of the presentation of diverticulitis is of interest, with visceral to subcutaneous ratio likely representing a predictive value of more complicated disease ${ }^{92}$, in accordance with obesity as a risk factor for $\mathrm{AD}$.

Bacterial translocation from the diverticula wall to the perivisceral area can also activate TLRs expressed on human colonic muscular cells ${ }^{93}$. LPS binding to TLR4 is capable of triggering persistent and long-term oxidation-driven phenotypic myogenic cellular alterations ${ }^{94}$, which are conceivably associated with a smooth muscle cell 'shift' toward the synthetic phenotype $\mathrm{e}^{95}$, resulting in a functional impairment of human colonic smooth muscle cells. Massive intramuscular fibrosis of both muscle layers has been described in $\mathrm{DD}^{96}$ and recently fibrosis, not predictable on endoscopic mucosal biopsies, has also been detected in DD submucosa ${ }^{97}$. Of note is that maximum colonic wall thickness is one of the factors used to predict recurrent diverticulitis ${ }^{98}$. This observed fibrotic trend could be influenced by NSAIDs, a known risk factor for AD and recurrences, that cause an enteropathy characterized by multiple short-segment strictures ${ }^{99}$. Part of the NSAID-induced damage in the gastrointestinal tract is caused by an uncoupling of mitochondrial oxidative phosphorylation that favors oxidative stress $^{100}$. Likewise, the protective effect of statins could be related to their possible anti-fibrotic effects ${ }^{101}$. The involvement of peridiverticular tissues might then contribute to the decrease in compliance leading to stiffer tissue that is more susceptible to tears, especially under conditions of increased luminal pressures favored by muscular hypertrophy.

\section{Acute diverticulitis management}

AD clinical classification and risk stratification is based on $\mathrm{CT}$, which is able to offer a more comprehensive evaluation of 
uncomplicated and complicated forms, and severity and management are graded with the use of modified Hinchey's criteria ${ }^{6}$. More recently, a detailed classification of $\mathrm{AD}$ was proposed by German guidelines based on CT and clinical laboratory criteria ${ }^{7}$ (Table 2). Among AD, roughly two-thirds of patients present with uncomplicated diverticulitis ${ }^{102}$.

In this setting, an important role might be provided by abdominal US, which, in the hands of experienced physicians, can be used as a sensitive and specific diagnostic tool ${ }^{7-10}$. A multicenter study evaluating the accuracy of US compared with CT in unselected patients referred for acute abdominal pain to the emergency department showed that CT has a higher sensitivity compared to US in detecting $\operatorname{AD}(81 \% \text { versus } 61 \% ; p=0.048)^{103}$. Currently, however, a strategy for providing CT after negative or inconclusive US has been proposed ${ }^{7,9,10}$.

There has been considerable focus over the past few decades on a conservative treatment strategy based on the administration of systemic antibiotics as well as on surgery either electively or in an emergency setting.

More than five years ago, Chabok et al. published the first prospective RCT in this area, the AVOD trial, showing that antibiotic treatment in patients with uncomplicated diverticulitis (without CT signs of abscess, fistula, or free air) neither accelerates recovery nor prevents complication or recurrences ${ }^{104}$. The most recent multicenter RCT of observational versus systemic antibiotic treatment (DIABOLO trial: amoxicillin plus clavulanic acid $1.2 \mathrm{~g}$ four times daily intravenously for at least 48 hours, after which the route was switched to oral administration of $625 \mathrm{mg}$ three times daily) for a first episode of CT-proven uncomplicated AD (Hinchey stages 1a and 1b) showed that observational treatment without antibiotics did not prolong recovery and can be considered appropriate in patients with uncomplicated diverticulitis ${ }^{19}$. However, even if no significant differences between Hinchey stages $1 \mathrm{a}$ and $1 \mathrm{~b}$ diverticulitis were found, it should be noted that the vast majority of patients included had a diagnosis of Hinchey stage 1a AD $(90.1 \%$ in the observational and $94 \%$ in the antibiotic-treated group) with only a small percentage of patients with Hinchey stage $1 \mathrm{~b}$ diverticulitis. Although these results suggested that antibiotics may not be necessary in patients with Hinchey stage $1 \mathrm{~b}$ diverticulitis, currently no strong evidence to treat these patients without antibiotics is available, and more data need to be collected. In fact, a recent systematic review of national and international guidelines recommended treating small abscesses with antibiotics $^{18}$. Moreover, only short-term results in omitting antibiotics were reported by both cited RCTs (AVOD and DIABOLO trials). More recently, the long-term effects of

Table 2. Acute diverticulitis management and classification according to modified Hinchey and German Society Gastroenterology classifications.

\begin{tabular}{|c|c|c|}
\hline $\begin{array}{l}\text { Modified Hinchey } \\
\text { Classification }\end{array}$ & $\begin{array}{l}\text { German society } \\
\text { Gastroenterology } \\
\text { Classification }\end{array}$ & Management \\
\hline \multirow{2}{*}{$\begin{array}{l}\text { 1a } \\
\text { Confined pericolonic phlegmon } \\
\text { and associated inflammation } \\
\text { without an organized fluid } \\
\text { collection }\end{array}$} & $\begin{array}{l}\text { 1a } \\
\text { No peridiverticulitis }\end{array}$ & \multirow{2}{*}{$\begin{array}{l}\text { Consider outpatients management } \\
\text { Not routine use of systemic antibiotic*}\end{array}$} \\
\hline & $\begin{array}{l}\text { 1b } \\
\text { Pericolonic phlegmon }\end{array}$ & \\
\hline $1 b$ & $2 a$ & \\
\hline $\begin{array}{l}\text { Pericolonic abscess less than } \\
4 \mathrm{~cm} \text { in size, adjacent to the } \\
\text { area of diverticulitis }\end{array}$ & $\begin{array}{l}\text { Concealed perforation abscess } \\
\leq 1 \mathrm{~cm}\end{array}$ & $\begin{array}{l}\text { Hospitalization } \\
\text { Bowel rest, parenteral fluids } \\
\text { Systemic antibiotic }\end{array}$ \\
\hline 2 & $2 b$ & \\
\hline \multirow[t]{2}{*}{$\begin{array}{l}\text { Pelvic or inter-loop abscess, or } \\
\text { abscess larger than } 4 \mathrm{~cm}\end{array}$} & $\begin{array}{l}\text { Paracolic or mesocolic abscess } \\
>1 \mathrm{~cm}\end{array}$ & $\begin{array}{l}\text { Hospitalization } \\
\text { Bowel rest, parenteral fluids } \\
\text { Systemic antibiotic } \\
\text { Consider Ultrasonography- or CT-guided } \\
\text { drainage } \\
\text { Consider surgery }\end{array}$ \\
\hline & $\begin{array}{l}\mathbf{2 c} \\
\text { Free perforation }\end{array}$ & \multirow{3}{*}{$\begin{array}{l}\text { Hospitalization } \\
\text { Bowel rest, parenteral fluids, } \\
\text { Systemic antibiotic } \\
\text { Consider laparoscopic lavage/surgery }\end{array}$} \\
\hline $\begin{array}{l}3 \\
\text { Purulent peritonitis }\end{array}$ & $\begin{array}{l}\mathbf{2 c 1} \\
\text { Purulent peritonitis }\end{array}$ & \\
\hline $\begin{array}{l}4 \\
\text { Fecal peritonitis }\end{array}$ & $\begin{array}{l}2 c 2 \\
\text { Fecal peritonitis }\end{array}$ & \\
\hline
\end{tabular}

*except for immunocompromised patients and severe comorbidities 
omitting antibiotics in uncomplicated AD were assessed after 24 months' follow-up of the DIABOLO trial ${ }^{105}$. In the observational group, even if no significant differences were found in terms of recurrent diverticulitis and sigmoid resection, a higher number of elective resections was reported. Accordingly, the most recent European ${ }^{7-10,106,107}$ and American $^{108}$ guidelines suggest the non-routine use of systemic antibiotics in patients with uncomplicated AD (Table 2). The need of hospitalization has been reconsidered as well, and a recent systematic review supported the safety, efficacy, and economic efficiency of an outpatient-based treatment approach ${ }^{109}$.

The management of complicated AD depends on its severity and complexity, requiring hospitalization, bowel rest, parenteral fluids, and, in selected cases, surgery. Antibiotic therapy is part of the management of complicated diverticulitis, and recent European guidelines ${ }^{7-10,106,107}$ are in accordance in recommending the use of broad-spectrum antibiotics (Table 2).

How to best treat complicated AD with surgery has been under debate and subject to notable changes recently. In particular, the number of episodes is not the only indication for surgery in patients with recurring diverticulitis: the individual case and course is also taken into account. A recent open-label randomized multicenter trial (DIRECT trial) randomized 109 patients after an episode of $\mathrm{AD}$ to receive surgical treatment or conservative management ${ }^{110}$. After a brief follow-up of 6 months, elective sigmoidectomy resulted in a better quality of life (assessed by many specific questionnaires) compared to conservative management. These results, even if innovative, might be affected by the heterogeneity of patients included (both patients with recurrent diverticulitis and patients with persistent abdominal complaints). In this setting, clinicians should carefully assess the relationship between symptoms and colonic diverticula differentiating abdominal complaints from irritable bowel syndrome, whose prevalence might increase after an episode of $\mathrm{AD}^{24}$.

Currently, the decision to perform an elective resection after one or more episodes of AD should be undertaken on a case-by-case basis, taking into account risk factors, complications, age, and severity of episodes as well as the patient's personal circumstances and comorbidities (i.e. immunosuppressed patients) ${ }^{111,112}$.

Actually, the possible recognition of clinical or biochemical parameters that could be used to identify patients who progress from uncomplicated to complicated $\mathrm{AD}$ and to monitor the potential development of complications requiring immediate surgical intervention are matters of debate. Procalcitonin ${ }^{113}$ and neutrophil count and white cell to lymphocyte ratio ${ }^{114}$ have been proposed as accurate markers to differentiate complicated from uncomplicated diverticulitis, and higher levels of calprotectin, an inflammatory colonic mucosal marker, tend to be associated with more severe $\mathrm{AD}^{25}$. Clinical predictors of early recurrences up to 6 months after a first episode of $\mathrm{AD}$ appear to be high C-reactive protein (CRP) levels ${ }^{115}$, the presence of systemic inflammatory response syndrome, high pain score, and regular steroid or immunomodulator use ${ }^{116}$. For now, the proper timing of surgically treating $\mathrm{AD}$ remains undetermined, with surgical resection probably being reserved for patients with severe recurrences. Abscess formation should be treated by ultrasonography- or CT guided drainage while patients with signs of free perforation should undergo immediate surgery. Because of advancements in interventional technologies and laparoscopic treatment methods, surgical therapy is primarily aimed towards the control of emergency situations and avoidance of Hartmann's procedures $^{112}$.

\section{Medical strategies for acute diverticulitis prevention}

Treatment protocols in $\mathrm{DD}$, especially for $\mathrm{AD}$ prevention, have been recently summarized ${ }^{117}$. In $\mathrm{AD}$ prevention, epidemiological studies suggested that people consuming the highest quantity of fiber had a $41 \%$ lower risk of developing DD (0.59, 0.46 to $0.78 ; p<0.001)$ in comparison with those consuming less fiber ${ }^{46}$, with the reduced risk being strongest for cereal and fruit fiber ${ }^{39}$. This is in accordance with many national guidelines ${ }^{7-10,106,107}$ supporting their use.

Regarding rifaximin, recent evidence ${ }^{118}$ confirms that short monthly cycles of rifaximin with fiber supplementation may reduce the risk of $\mathrm{AD}$ occurrence, even if the number needed to treat (NNT) to prevent an episode of AD in one year was $57^{119}$. Despite the high NNT, Polish ${ }^{107}$ and Italian ${ }^{9,10}$ guidelines recommend the use of rifaximin associated with fiber intake. Data regarding the use of rifaximin for the secondary prevention of $\mathrm{AD}$ are weak, and recent guidelines did not agree with each other, with some for $^{8-10}$ and others against ${ }^{7,108}$ its use. The most recent open RCT evaluated the efficacy of one-year intermittent rifaximin plus fiber to prevent $\mathrm{AD}$ recurrence ${ }^{120}$. After randomization, the underpowered number of patients included caused a study switch from evidence gathering to proof of concept. However, the authors reported that rifaximin was more effective compared to fiber alone in the secondary prevention of $\mathrm{AD}$, with recurrence occurring in $10.4 \%$ versus $19.3 \%$ of patients, respectively $(p=0.033)$.

Data regarding the use of mesalazine are inconclusive and more studies are needed, even if some positive results emerged for AD primary prevention ${ }^{121}$. Recently, the role of mesalazine in the secondary prevention of $\mathrm{AD}$ has been investigated by several RCTs ${ }^{122,123}$ that showed that mesalazine is not significantly superior to placebo in preventing AD recurrence. A recent Cochrane systematic review ${ }^{124}$ confirmed the uncertain role for mesalazine and its effects on $\mathrm{AD}$ recurrence, and a similar conclusion was drawn by a recent meta-analysis ${ }^{125}$.

\section{Conclusion: possible tailored therapeutic strategies}

In the last few years, the main goal that has been achieved in the management of $\mathrm{AD}$ is that uncomplicated $\mathrm{AD}$ can, to a larger extent, be managed on an outpatient basis with no or little supportive therapy, a strategy that will certainly impact on the health-related costs of this disease. A second achievement, one that needs more controlled studies, is the finding that one primary preventive intervention in $\mathrm{AD}$ is diet, specifically an adequate intake of fiber. The preferred type of fiber still needs to be elucidated considering that a high content in a FODMAP diet could cause an increase in colonic gas and fluids due to fermentation $^{126}$. 
Some other topics, mainly concerning $\mathrm{AD}$ recurrences, remain topics of debate. There is also a need of robust well-designed placebo-controlled RCTs that take into account the clinical history of the patient in order to achieve clearer evidence.

Because of an ascertained multifactorial pathogenesis of uncomplicated and complicated $\mathrm{AD}$, it is likely that a single 'causa prima' will be not identifiable. In turn, it would be useful to stratify patients in order to separate those who could respond to lifestyle modifications from those with more aggressive disease who could be treated better with surgery. It is possible that besides age-dependent alterations, different pathogenic phenotypes might characterize more aggressive and complicated DD, such as those observed in younger people. A better stratification or a longer and more careful observation of the natural history of the diverticulosis versus diverticulitis process could be helpful to verify this hypothesis. It must be kept in mind that the actual therapeutic strategies (anti-inflammatory drugs, non-absorbable antibiotics, and probiotics), targeted towards luminal alterations, more easily demonstrated by the use of endoscopic samples, showed unsatisfactory efficacy in primary and secondary prevention. A better understanding of the different possible factors involved will be of great help in the planning of different possible therapeutic strategies, such as the use of nutraceuticals, and in pursuing tailored therapeutic algorithm strategies.

\section{Competing interests}

The authors declare that they have no competing interests.

\section{Grant information}

Carola Severi receives funding from the University Sapienza of Rome, 000324_17_RS_SEVERI_SAPIENZA_PROGETTI 2016.

The funders had no role in study design, data collection and analysis, decision to publish, or preparation of the manuscript.

\section{Acknowledgements}

The authors thank Dr Laura Carabotti for the art work of the Figure.
1. Stollman N, Raskin JB: Diverticular disease of the colon. Lancet. 2004; 363(9409): 631-9.

PubMed Abstract | Publisher Full Text

2. Feuerstein JD, Falchuk KR: Diverticulosis and Diverticulitis. Mayo Clin Proc 2016; 91(8): 1094-104.

PubMed Abstract | Publisher Full Text

3. Shahedi K, Fuller G, Bolus R, et al.: Long-term risk of acute diverticulitis among patients with incidental diverticulosis found during colonoscopy. Clin Gastroenterol Hepatol. 2013; 11(12): 1609-13.

PubMed Abstract | Publisher Full Text | Free Full Text

4. Cuomo R, Barbara G, Annibale B: Rifaximin and diverticular disease: Position paper of the Italian Society of Gastroenterology (SIGE). Dig Liver Dis. 2017; 49(6): 595-603.

PubMed Abstract | Publisher Full Text

5. Bharucha AE, Parthasarathy G, Ditah I, et al:: Temporal Trends in the Incidence and Natural History of Diverticulitis: A Population-Based Study. Am J Gastroenterol. 2015; 110(11): 1589-96.

PubMed Abstract | Publisher Full Text | Free Full Text

6. Kaiser AM, Jiang JK, Lake JP, et al.: The management of complicated diverticulitis and the role of computed tomography. Am J Gastroenterol. 2005; 100(4): 910-7.

PubMed Abstract | Publisher Full Text

7. Kruis W, Germer CT, Leifeld L: Diverticular disease: guidelines of the german society for gastroenterology, digestive and metabolic diseases and the german society for general and visceral surgery. Digestion. 2014; 90(3): 190-207. PubMed Abstract | Publisher Full Text

8. Andeweg CS, Mulder IM, Felt-Bersma RJ, et al.: Guidelines of diagnostics and treatment of acute left-sided colonic diverticulitis. Dig Surg. 2013; 30(4-6): 278-92.

PubMed Abstract | Publisher Full Text

9. Cuomo R, Barbara G, Pace F, et al:: Italian consensus conference for colonic diverticulosis and diverticular disease. United European Gastroenterol J. 2014; 2(5): 413-42.

PubMed Abstract | Publisher Full Text | Free Full Text

10. Binda GA, Cuomo R, Laghi A, et al:: Practice parameters for the treatment of colonic diverticular disease: Italian Society of Colon and Rectal Surgery (SICCR) guidelines. Tech Coloproctol. 2015; 19(10): 615-26. PubMed Abstract | Publisher Full Text

11. Wheat CL, Strate LL: Trends in Hospitalization for Diverticulitis and Diverticular Bleeding in the United States From 2000 to 2010. Clin Gastroenterol Hepatol. 2016; 14(1): 96-103.e1.

PubMed Abstract | Publisher Full Text | Free Full Text

12. F Peery AF, Dellon ES, Lund J, et al:: Burden of gastrointestinal disease in the United States: 2012 update. Gastroenterology. 2012; 143(5): 1179-87.e1-3. PubMed Abstract | Publisher Full Text | Free Full Text | F1000 Recommendation

13. Bollom A, Austrie J, Hirsch W, et al.: Emergency Department Burden of Diverticulitis in the USA, 2006-2013. Dig Dis Sci. 2017; 62(10): 2694-703. PubMed Abstract | Publisher Full Text | Free Full Text

14. Mennini FS, Sciattella P, Marcellusi A, et al.: Economic burden of diverticular disease: An observational analysis based on real world data from an Italian region. Dig Liver Dis. 2017; 49(9): 1003-8. PubMed Abstract | Publisher Full Text

15. Paterson HM, Arnott ID, Nicholls RJ, et al:: Diverticular disease in Scotland: 2000-2010. Colorectal Dis. 2015; 17(4): 329-34. PubMed Abstract | Publisher Full Text

16. van Dijk ST, Rottier SJ, van Geloven AAW, et al.: Conservative Treatment of Acute Colonic Diverticulitis. Curr Infect Dis Rep. 2017; 19(11): 44. PubMed Abstract | Publisher Full Text | Free Full Text

17. Joliat G, Emery J, Demartines N, et al:: Antibiotic treatment for uncomplicated and mild complicated diverticulitis: outpatient treatment for everyone. Int $J$ Colorectal Dis. 2017; 32(9): 1313-9. PubMed Abstract | Publisher Full Text

18. F Galetin T, Galetin A, Vestweber KH, et al.: Systematic review and comparison of national and international guidelines on diverticular disease. Int J Colorectal Dis. 2018; 33(3): 261-72. PubMed Abstract | Publisher Full Text | F1000 Recommendation

19. F Daniels L, Ünlü Ç, de Korte N, et al.: Randomized clinical trial of observational versus antibiotic treatment for a first episode of CT-proven uncomplicated acute diverticulitis. Br J Surg. 2017; 104(1): 52-61. PubMed Abstract | Publisher Full Text | F1000 Recommendation

20. F El-Sayed C, Radley S, Mytton J, et al.: Risk of Recurrent Disease and Surgery Following an Admission for Acute Diverticulitis. Dis Colon Rectum. 2018; 61(3): 382-9.

PubMed Abstract | Publisher Full Text | F1000 Recommendation

21. Buchs NC, Mortensen NJ, Ris F, et al.: Natural history of uncomplicated sigmoid diverticulitis. World J Gastrointest Surg. 2015; 7(11): 313-8. PubMed Abstract | Publisher Full Text | Free Full Text

22. Chabok A, Andreasson $\mathrm{K}$, Nikberg M: Low risk of complications in patients with first-time acute uncomplicated diverticulitis. Int J Colorectal Dis. 2017; 32(12): 1699-702.

PubMed Abstract | Publisher Full Text | Free Full Text

23. Mizrahi I, Al-Kurd A, Chapchay K, et al:: Long-term outcomes of sigmoid diverticulitis: a single-center experience. J Surg Res. 2018; 221: 8-14. PubMed Abstract | Publisher Full Text

24. Cohen E, Fuller G, Bolus R, et al.: Increased risk for irritable bowel syndrome 
after acute diverticulitis. Clin Gastroenterol Hepatol. 2013; 11(12): 1614-9. PubMed Abstract | Publisher Full Text | Free Full Text

25. Lahat A, Necula D, Yavzori M, et al:: Prolonged Recurrent Abdominal Pain is Associated With Ongoing Underlying Mucosal Inflammation in Patients who had an Episode of Acute Complicated Diverticulitis. J Clin Gastroenterol. 2018. PubMed Abstract | Publisher Full Text

26. F Andeweg CS, Berg R, Staal JB, et al.: Patient-reported Outcomes After Conservative or Surgical Management of Recurrent and Chronic Complaints of Diverticulitis: Systematic Review and Meta-analysis. Clin Gastroenterol Hepatol. 2016; 14(2): 183-90.

PubMed Abstract | Publisher Full Text | F1000 Recommendation

27. Peery AF: Colonic Diverticula and Diverticular Disease: 10 Facts Clinicians Should Know. N C Med J. 2016; 77(3): 220-2.

PubMed Abstract | Publisher Full Text | Free Full Text

28. F Jamal Talabani A, Lydersen S, Ness-Jensen E, et al.: Risk factors of admission for acute colonic diverticulitis in a population-based cohort study: The North Trondelag Health Study, Norway. World J Gastroenterol. 2016; 22(48): The North $10663-72$.

PubMed Abstract | Publisher Full Text | Free Full Text | F1000 Recommendation

29. F Aune D, Sen A, Leitzmann MF, et al:: Body mass index and physical activity and the risk of diverticular disease: a systematic review and meta-analysis of prospective studies. Eur J Nutr. 2017; 56(8): 2423-38.

PubMed Abstract | Publisher Full Text | Free Full Text | F1000 Recommendation

30. Strate LL, Liu YL, Aldoori WH, et al:: Obesity increases the risks of diverticulitis and diverticular bleeding. Gastroenterology. 2009; 136(1): 115-122.e1. PubMed Abstract | Publisher Full Text | Free Full Text

31. F Humes DJ, Ludvigsson JF, Jarvholm B: Smoking and the Risk of Hospitalization for Symptomatic Diverticular Disease: A Population-Based Cohort Study from Sweden. Dis Colon Rectum. 2016; 59(2): 110-4. PubMed Abstract | Publisher Full Text | F1000 Recommendation

32. F Aune D, Sen A, Leitzmann MF, et al:: Tobacco smoking and the risk of diverticular disease - a systematic review and meta-analysis of prospective studies. Colorectal Dis. 2017; 19(7): 621-33.

PubMed Abstract | Publisher Full Text | F1000 Recommendation

33. Diamant MJ, Schaffer S, Coward S, et al:: Smoking Is Associated with an Increased Risk for Surgery in Diverticulitis: A Case Control Study. PLoS One. 2016; 11(7): e0153871.

PubMed Abstract | Publisher Full Text | Free Full Text

34. F Cao Y, Strate LL, Keeley BR, et al.: Meat intake and risk of diverticulitis among men. Gut. 2018; 67(3): 466-72.

PubMed Abstract | Publisher Full Text | Free Full Text | F1000 Recommendation

35. Kvasnovsky CL, Papagrigoriadis S, Bjarnason I: Increased diverticula complications with nonsteriodal anti-inflammatory drugs and other medications: a systematic review and meta-analysis. Colorectal Dis. 2014; 16(6): 0189-96.

PubMed Abstract | Publisher Full Text

36. F Strate LL, Liu YL, Huang ES, et al.: Use of aspirin or nonsteroidal antiinflammatory drugs increases risk for diverticulitis and diverticular bleeding. Gastroenterology. 2011; 140(5): 1427-33.

PubMed Abstract | Publisher Full Text | Free Full Text | F1000 Recommendation

37. Humes DJ, Fleming KM, Spiller RC, et al:: Concurrent drug use and the risk of perforated colonic diverticular disease: a population-based case-control study. Gut. 2011; 60(2): 219-24. PubMed Abstract | Publisher Full Text

38. Strate LL, Liu YL, Aldoori WH, et al:: Physical activity decreases diverticular complications. Am J Gastroenterol. 2009; 104(5): 1221-30.

PubMed Abstract | Publisher Full Text | Free Full Text

39. Crowe FL, Balkwill A, Cairns BJ, et al.: Source of dietary fibre and diverticular disease incidence: a prospective study of UK women. Gut. 2014; 63(9): 1450-6. PubMed Abstract | Publisher Full Text | Free Full Text

40. Strate LL: Lifestyle factors and the course of diverticular disease. Dig Dis. 2012; 30(1): $35-45$

PubMed Abstract | Publisher Full Text

41. F Sköldberg F, Svensson T, Olén O, et al:: A population-based case-control study on statin exposure and risk of acute diverticular disease. Scand $J$ Gastroenterol. 2016; 51(2): 203-10.

PubMed Abstract | Publisher Full Text | F1000 Recommendation

42. Maguire LH, Song M, Strate LE, et al.: Higher serum levels of vitamin D are associated with a reduced risk of diverticulitis. Clin Gastroenterol Hepatol. 2013; 11(12): 1631-5.

PubMed Abstract | Publisher Full Text | Free Full Text

43. Tursi A, Elisei W, Picchio M, et al.: Serum levels of vitamin D are associated with the severity of the endoscopic appearance of diverticular disease of the colon according to DICA classification. J Gastrointestin Liver Dis. 2016; 25(4): 567-8. PubMed Abstract | Publisher Full Text

44. Aldoori WH, Giovannucci EL, Rimm EB, et al:: A prospective study of alcohol, smoking, caffeine, and the risk of symptomatic diverticular disease in men. Ann Epidemiol. 1995; 5(3): 221-8.

PubMed Abstract | Publisher Full Text

45. Tønnesen H, Engholm G, Moller H: Association between alcoholism and diverticulitis. Br J Surg. 1999; 86(8): 1067-8.

PubMed Abstract

46. Crowe FL, Appleby PN, Allen NE, et al: Diet and risk of diverticular disease in Oxford cohort of European Prospective Investigation into Cancer and Nutrition (EPIC): prospective study of British vegetarians and non-vegetarians. BMJ. 2011; 343: d4131.

PubMed Abstract | Publisher Full Text | Free Full Text

47. Morris $\mathrm{CR}$, Harvey IM, Stebbings WS, et al: Do calcium channel blockers and antimuscarinics protect against perforated colonic diverticular disease? A case control study. Gut. 2003; 52(12): 1734-7.

PubMed Abstract | Publisher Full Text | Free Full Text

48. Nguyen GC, Sam J, Anand N: Epidemiological trends and geographic variation in hospital admissions for diverticulitis in the United States. World $J$ Gastroenterol. 2011; 17(12): 1600-5.

PubMed Abstract | Publisher Full Text | Free Full Text

49. Chang SS, Huang N, Hu HY: Patients with end-stage renal disease were at an increased risk of hospitalization for acute diverticulitis. Medicine (Baltimore). 2016; 95(39): e4881.

PubMed Abstract | Publisher Full Text | Free Full Text

50. Nikberg M, Ji J, Leppert J, et al.: Socioeconomic characteristics and comorbidities of diverticular disease in Sweden 1997-2012. Int $J$ Colorectal Dis. 2017; 32(11): 1591-6.

PubMed Abstract | Publisher Full Text | Free Full Text

51. Strate LL, Erichsen R, Baron JA, et al.: Heritability and familial aggregation of diverticular disease: a population-based study of twins and siblings. Gastroenterology. 2013; 144(4): 736-742.e1; quiz e14.

PubMed Abstract | Publisher Full Text

52. Connelly TM, Berg AS, Hegarty JP, et al:: The TNFSF15 gene single nucleotide polymorphism rs7848647 is associated with surgical diverticulitis. Ann Surg. 2014; 259(6): 1132-7. PubMed Abstract | Publisher Full Text

53. Coble JL, Sheldon KE, Yue F, et al:: Identification of a rare LAMB4 variant associated with familial diverticulitis through exome sequencing. Hum Mol Genet. 2017; 26(16): 3212-20.

PubMled Abstract | Publisher Full Text

54. Strate LL, Liu YL, Syngal S, et al:: Nut, corn, and popcorn consumption and the incidence of diverticular disease. JAMA. 2008; 300(8): 907-14.

PubMed Abstract | Publisher Full Text | Free Full Text

55. Carabotti M, Cuomo R, Barbara G, et al:: Demographic and clinical features distinguish subgroups of diverticular disease patients: Results from an Italian nationwide registry. United European Gastroenterol J. 2018; 43 205064061876495.

Publisher Full Text

56. F Hupfeld L, Burcharth J, Pommergaard HC, et al:: Risk factors for recurrence after acute colonic diverticulitis: a systematic review. Int J Colorectal Dis. 2017; 32(5): 611-22.

PubMed Abstract | Publisher Full Text | F1000 Recommendation

57. F Wedel T, Barrenschee M, Lange C, et al:: Morphologic Basis for Developing Diverticular Disease, Diverticulitis, and Diverticular Bleeding. Viszeralmedizin. 2015; 31(2): 76-82

PubMed Abstract | Publisher Full Text | Free Full Text | F1000 Recommendation

58. Walker MM: Inflammation, Genetics, Dysbiosis, and the Environment: New Paradigms for Diagnosis in Complex Chronic Gut Syndromes. J Clin Gastroenterol. 2016; 50 Suppl 1: S4-5.

PubMed Abstract | Publisher Full Tex

59. Rezapour M, Ali S, Stollman N: Diverticular Disease: An Update on Pathogenesis and Management. Gut Liver. 2018; 12(2): 125-32. PubMed Abstract | Publisher Full Text | Free Full Text

60. Daniels L, Philipszoon LE, Boermeester MA: A hypothesis: important role for gut microbiota in the etiopathogenesis of diverticular disease. Dis Colon Rectum. 2014; 57(4): 539-43.

PubMed Abstract | Publisher Full Text

61. F Barbara G, Scaioli E, Barbaro MR, et al.: Gut microbiota, metabolome and immune signatures in patients with uncomplicated diverticular disease. Gut. 2017; 66(7): 1252-61.

PubMed Abstract | Publisher Full Text | F1000 Recommendation

62. F Thevaranjan N, Puchta A, Schulz C, et al:: Age-Associated Microbial Dysbiosis Promotes Intestinal Permeability, Systemic Inflammation, and Macrophage Dysfunction. Cell Host Microbe. 2017; 21: 455-466.e4. PubMed Abstract | Publisher Full Text | Free Full Text | F1000 Recommendation

63. F Koeth RA, Wang Z, Levison BS, et al.: Intestinal microbiota metabolism of L-carnitine, a nutrient in red meat, promotes atherosclerosis. Nat Med. 2013; 19(5): 576-85.

PubMed Abstract | Publisher Full Text | Free Full Text | F1000 Recommendation

64. Le Leu RK, Young GP, Hu Y, et al:: Dietary red meat aggravates dextran sulfate sodium-induced colitis in mice whereas resistant starch attenuates inflammation. Dig Dis Sci. 2013; 58(12): 3475-82.

PubMed Abstract | Publisher Full Text

65. Breton J, Plé C, Guerin-Deremaux L, et al:: Intrinsic immunomodulatory effects of low-digestible carbohydrates selectively extend their anti-inflammatory prebiotic potentials. Biomed Res Int. 2015; 2015: 162398.

PubMed Abstract | Publisher Full Text | Free Full Text 
66. F David LA, Maurice CF, Carmody RN, et al.: Diet rapidly and reproducibly alters the human gut microbiome. Nature. 2014; 505(7484): 559-63. PubMed Abstract | Publisher Full Text | Free Full Text | F1000 Recommendation

67. Lamps LW, Knapple WL: Diverticular disease-associated segmental colitis. Clin Gastroenterol Hepatol. 2007; 5(1): 27-31.

PubMed Abstract | Publisher Full Text

68. von Rahden BH, Kircher S, Thiery S, et al:: Association of steroid use with complicated sigmoid diverticulitis: potential role of activated CD68+/CD163+ macrophages. Langenbecks Arch Surg. 2011; 396(6): 759-68. PubMed Abstract | Publisher Full Text

69. Turco F, Andreozzi P, Palumbo I, et al:: Bacterial stimuli activate nitric oxide colonic mucosal production in diverticular disease. Protective effects of $L$. casei DG@ (Lactobacillus paracasei CNCM I-1572). United European Gastroenterol J. 2017; 5(5): 715-24.

PubMed Abstract | Publisher Full Text | Free Full Text

70. F Peery AF, Keku TO, Addamo C, et al: Colonic Diverticula Are Not Associated With Mucosal Inflammation or Chronic Gastrointestinal Symptoms. Clin Gastroenterol Hepatol. 2018; 16(6): 884-891.e1.

PubMed Abstract | Publisher Full Text | Free Full Text | F1000 Recommendation

71. Zeng MY, Inohara N, Nuñez G: Mechanisms of inflammation-driven bacterial dysbiosis in the gut. Mucosal Immunol. 2017; 10(1): 18-26. PubMed Abstract | Publisher Full Text | Free Full Text

72. Guarino MP, Cicala M, Putignani L, et al.: Gastrointestinal neuromuscular apparatus: An underestimated target of gut microbiota. World J Gastroenterol. 2016; 22(45): 9871-9.

PubMed Abstract | Publisher Full Text | Free Full Text

73. Bassotti G, Villanacci V: Colonic diverticular disease: abnormalities of neuromuscular function. Dig Dis. 2012; 30(1): 24-8. PubMed Abstract | Publisher Full Text

74. Bassotti G, Battaglia E, Spinozzi F, et al:: Twenty-four hour recordings of colonic motility in patients with diverticular disease: evidence for abnormal motility and propulsive activity. Dis Colon Rectum. 2001; 44(12): 1814-20. PubMed Abstract | Publisher Full Text

75. Fornai M, Colucci R, Antonioli L, et al:: Role of cyclooxygenase isoforms in the altered excitatory motor pathways of human colon with diverticular disease. Br J Pharmacol. 2014; 171(15): 3728-40. PubMed Abstract | Publisher Full Text | Free Full Text

76. Simpson J, Sundler F, Humes DJ, et al:: Post inflammatory damage to the enteric nervous system in diverticular disease and its relationship to symptoms. Neurogastroenterol Motil. 2009; 21(8): 847-e58.

PubMed Abstract | Publisher Full Text

77. Golder M, Burleigh DE, Belai A, et al.: Smooth muscle cholinergic denervation hypersensitivity in diverticular disease. Lancet. 2003; 361(9373): 1945-51. PubMed Abstract | Publisher Full Text

78. Golder M, Burleigh DE, Ghali L, et al:: Longitudinal muscle shows abnorma relaxation responses to nitric oxide and contains altered levels of NOS1 and elastin in uncomplicated diverticular disease. Colorectal Dis. 2007; 9(3): 218-28.

PubMed Abstract | Publisher Full Text

79. Whiteway J, Morson BC: Elastosis in diverticular disease of the sigmoid colon Gut. 1985; 26(3): 258-66. PubMed Abstract | Publisher Full Text | Free Full Text

80. Hellwig I, Böttner M, Barrenschee M, et al: Alterations of the enteric smooth musculature in diverticular disease. J Gastroenterol. 2014; 49(8): 1241-52. PubMed Abstract | Publisher Full Tex

81. Deduchovas O, Saladzinskas Z, Tamelis A, et al: Morphologic pattern of myenteric neural plexus in colonic diverticular disease. A whole-mount study employing histochemical staining for acetylcholinesterase. Ann Anat. 2008: 190(6): 525-30.

PubMed Abstract | Publisher Full Text

82. Iwase H, Sadahiro S, Mukoyama S, et al:: Morphology of myenteric plexuses in the human large intestine: comparison between large intestines with and without colonic diverticula. J Clin Gastroenterol. 2005; 39(8): 674-8. PubMed Abstract | Publisher Full Text

83. Wedel T, Büsing V, Heinrichs $G$, et al:: Diverticular disease is associated with an enteric neuropathy as revealed by morphometric analysis. Neurogastroenterol Motil. 2010; 22(4): 407-14, e93-4. PubMed Abstract | Publisher Full Text

84. Pantaroto M, Lopes Filho Gde J, Pinto CA, et al.: Comparative study of collagen deposition in the colon wall of patients operated for sigmoid diverticular disease. Acta Cir Bras. 2015; 30(10): 715-9.

PubMed Abstract | Publisher Full Text

85. Pallotta L, Scirocco A, Ignazzi A, et al.: Inflammatory and phenotypic smooth muscle alterations in colonic diverticulosis and diverticular disease. [abstract] Gastroenterology. 2017; 152(5, Supplement 1): S50. Publisher Full Text

86. F Brown SR, Cleveland EM, Deeken CR, et al:: Type I/type III collagen ratio associated with diverticulitis of the colon in young patients. J Surg Res. 2017; 207: 229-34.

PubMed Abstract | Publisher Full Text | F1000 Recommendation

87. Galligan JJ, Sternini C: Insights into the Role of Opioid Receptors in the
GI Tract: Experimental Evidence and Therapeutic Relevance. Handb Exp Pharmacol. 2017; 239: 363-78.

PubMed Abstract | Publisher Full Text

88. Martinez-Cutillas M, Mañé N, Gallego D, et al:: EP and EP receptors mediate $\mathrm{PGE}_{2}$ induced relaxation in murine colonic circular muscle: pharmacological characterization. Pharmacol Res. 2014; 90: 76-86.

PubMed Abstract | Publisher Full Text

89. Gummesson A, Carlsson LM, Storlien LH, et al.: Intestinal permeability is associated with visceral adiposity in healthy women. Obesity (Silver Spring) 2011; 19(11): 2280-2.

PubMed Abstract | Publisher Full Tex

90. Büning $\mathrm{C}$, von Kraft $\mathrm{C}$, Hermsdorf $\mathrm{M}$, et al: Visceral Adipose Tissue in Patients with Crohn's Disease Correlates with Disease Activity, Inflammatory Markers, and Outcome. Inflamm Bowel Dis. 2015; 21(11): 2590-7.

PubMed Abstract | Publisher Full Text

91. Paeschke A, Erben U, Kredel LI, et al:: Role of visceral fat in colonic inflammation: from Crohn's disease to diverticulitis. Curr Opin Gastroenterol. 2017; 33(1): 53-8

PubMed Abstract | Publisher Full Tex

92. $\mathrm{F}$ Docimo S Jr, Lee $\mathrm{Y}$, Chatani $\mathrm{P}$, et al:: Visceral to subcutaneous fat ratio predicts acuity of diverticulitis. Surg Endosc. 2017; 31(7): 2808-12. PubMed Abstract | Publisher Full Text | F1000 Recommendation

93. Tattoli I, Petitta C, Scirocco A, et al.: Microbiota, innate immune system, and gastrointestinal muscle: ongoing studies. J Clin Gastroenterol. 2012; 46 Suppl: S6-11.

PubMed Abstract | Publisher Full Text

94. Matarrese P, Petitta C, Scirocco A, et al: Antioxidants counteract lipopolysaccharide-triggered alterations of human colonic smooth muscle cells. Free Radic Biol Med. 2012; 53(11): 2102-11.

PubMed Abstract | Publisher Full Text

95. Scirocco A, Matarrese P, Carabotti M, et al: Cellular and Molecular Mechanism of Phenotypic Switch in Gastrointestinal Smooth Muscle. J Cell Physiol. 2016; 231(2): 295-302.

PubMed Abstract | Publisher Full Text

96. Böttner M, Wedel T: Abnormalities of neuromuscular anatomy in diverticular disease. Dig Dis. 2012; 30(1): 19-23.

PubMed Abstract | Publisher Full Text

97. F Gordon IO, Agrawal N, Willis E, et al.: Fibrosis in ulcerative colitis is directly linked to severity and chronicity of mucosal inflammation. Aliment Pharmacol Ther. 2018; 47(7): 922-39.

PubMed Abstract | Publisher Full Text | Free Full Text | F1000 Recommendation

98. Dickerson EC, Chong ST, Ellis JH, et al.: Recurrence of Colonic Diverticulitis: Identifying Predictive CT Findings-Retrospective Cohort Study. Radiology. 2017; 285(3): 850-8.

PubMed Abstract | Publisher Full Text

99. Frye JM, Hansel SL, Dolan SG, et al.: NSAID enteropathy: appearance at CT and MR enterography in the age of multi-modality imaging and treatment. Abdom Imaging. 2015; 40(5): 1011-25. PubMed Abstract | Publisher Full Text

100. Bjarnason I, Scarpignato C, Holmgren E, et al.: Mechanisms of Damage to the Gastrointestinal Tract From Nonsteroidal Anti-Inflammatory Drugs. Gastroenterology. 2018; 154(3): 500-14 PubMed Abstract | Publisher Full Text

101. Price JC, Tien PC: Editorial: Statins and Liver Disease: Is it Time to Recommend Statins to Prevent Liver Disease Progression? Am J Gastroenterol. 2017; 112(10): 1506-7.

PubMed Abstract | Publisher Full Text

102. Li D, de Mestral C, Baxter NN, et al:: Risk of readmission and emergency surgery following nonoperative management of colonic diverticulitis: a population-based analysis. Ann Surg. 2014; 260(3): 423-30; discussion 430-1. PubMed Abstract | Publisher Full Text

103. van Randen A, Laméris W, van Es HW, et al:: A comparison of the accuracy of ultrasound and computed tomography in common diagnoses causing acute abdominal pain. Eur Radiol. 2011; 21(7): 1535-45. PubMed Abstract | Publisher Full Text | Free Full Text

104. Chabok A, Påhlman L, Hjern F, et al:: Randomized clinical trial of antibiotics in acute uncomplicated diverticulitis. Br J Surg. 2012; 99(4): 532-9. PubMed Abstract | Publisher Full Text

105. $F$ van Dijk ST, Daniels L, Ünlü Ç, et al.: Long-Term Effects of Omitting Antibiotics in Uncomplicated Acute Diverticulitis. Am J Gastroenterol. 2018. PubMed Abstract | Publisher Full Text | F1000 Recommendation

106. Andersen JC, Bundgaard L, Elbrønd H, et al.: Danish national guidelines for treatment of diverticular disease. Dan Med J. 2012; 59(5): C4453. PubMed Abstract

107. Pietrzak A, Bartnik W, Szczepkowski M, et al:: Polish interdisciplinary consensus on diagnostics and treatment of colonic diverticulosis (2015). Pol Przegl Chir. 2015; 87(4): 203-20. PubMed Abstract | Publisher Full Text

108. Stollman N, Smalley W, Hirano I, et al.: American Gastroenterological Association Institute Guideline on the Management of Acute Diverticulitis. Gastroenterology. 2015; 149(7): 1944-9. PubMed Abstract | Publisher Full Text 
109. F Sánchez-Velázquez $P$, Grande L, Pera M: Outpatient treatment of uncomplicated diverticulitis: a systematic review. Eur J Gastroenterol Hepatol. 2016; 28(6): 622-7.

PubMed Abstract | Publisher Full Text | F1000 Recommendation

110. $F$ van de Wall BJM, Stam MAW, Draaisma WA, et al.: Surgery versus conservative management for recurrent and ongoing left-sided diverticulitis (DIRECT trial): an open-label, multicentre, randomised controlled trial. Lancet Gastroenterol Hepatol. 2017; 2(1): 13-22.

PubMed Abstract | Publisher Full Text | F1000 Recommendation

111. Morris AM, Regenbogen SE, Hardiman KM, et al.: Sigmoid diverticulitis: a systematic review. JAMA. 2014; 311(3): 287-97. PubMed Abstract | Publisher Full Text

112. Pfützer RH, Kruis W: Management of diverticular disease. Nat Rev Gastroenterol Hepatol. 2015; 12(11): 629-38. PubMed Abstract | Publisher Full Text

113. Jeger $\mathrm{V}$, Pop $\mathrm{R}$, Forudastan $\mathrm{F}$, et al: Is there a role for procalcitonin in differentiating uncomplicated and complicated diverticulitis in order to reduce antibiotic therapy? A prospective diagnostic cohort study. Swiss Med Wkly. 2017; 147: w14555. PubMed Abstract | Publisher Full Text

114. Reynolds IS, Heaney RM, Khan W, et al.: The Utility of Neutrophil to Lymphocyte Ratio as a Predictor of Intervention in Acute Diverticulitis. Dig Surg. 2017; 34(3): 227-32. PubMed Abstract | Publisher Full Text

115. Buchs NC, Konrad-Mugnier B, Jannot AS, et al:: Assessment of recurrence and complications following uncomplicated diverticulitis. Br J Surg. 2013; 100(7): 976-9; discussion 979. PubMed Abstract | Publisher Full Text

116. Jaung R, Kularatna M, Robertson JP, et al:: Uncomplicated Acute Diverticulitis: Identifying Risk Factors for Severe Outcomes. World J Surg. 2017; 41(9): 2258-65. PubMed Abstract | Publisher Full Text

117. Carabotti M, Annibale B: Treatment of diverticular disease: an update on latest evidence and clinical implications. Drugs Context. 2018; 7: 212526. PubMed Abstract | Publisher Full Text | Free Full Text
118. Banasiewicz T, Francuzik W, Bobkiewicz A, et al.: The influence of rifaximin on diverticulitis rate and quality of life in patients with diverticulosis. Pol Przegl Chir. 2017; 89(1): 22-31. PubMed Abstract | Publisher Full Text

119. Maconi G, Barbara G, Bosetti C, et al:: Treatment of diverticular disease of the colon and prevention of acute diverticulitis: a systematic review. Dis Colon Rectum. 2011; 54(10): 1326-38. PubMed Abstract | Publisher Full Text

120. Lanas A, Ponce J, Bignamini A, et al:: One year intermittent rifaximin plus fibre supplementation vs. fibre supplementation alone to prevent diverticulitis recurrence: a proof-of-concept study. Dig Liver Dis. 2013; 45(2): 104-9. PubMed Abstract | Publisher Full Text

121. F Tursi A, Brandimarte G, Elisei W, et al:: Randomised clinical trial: mesalazine and/or probiotics in maintaining remission of symptomatic uncomplicated diverticular disease--a double-blind, randomised, placebo-controlled study. Aliment Pharmacol Ther. 2013; 38(7): 741-51. PubMed Abstract | Publisher Full Text | F1000 Recommendation

122. Raskin JB, Kamm MA, Jamal MM, et al.: Mesalamine did not prevent recurrent diverticulitis in phase 3 controlled trials. Gastroenterology. 2014; 147(4): 793-802. PubMed Abstract | Publisher Full Text

123. $\mathrm{F}$ Kruis W, Kardalinos $\mathrm{V}$, Eisenbach $\mathrm{T}$, et al:: Randomised clinical trial: mesalazine versus placebo in the prevention of diverticulitis recurrence. Aliment Pharmacol Ther. 2017; 46(3): 282-91. PubMed Abstract | Publisher Full Text | Free Full Text | F1000 Recommendation

124. F Carter F, Alsayb M, Marshall JK, et al.: Mesalamine (5-ASA) for the prevention of recurrent diverticulitis. Cochrane Database Syst Rev. 2017; 10: CD009839. PubMed Abstract | Publisher Full Text | F1000 Recommendation

125. Khan MA, Ali B, Lee WM, et al:: Mesalamine Does Not Help Prevent Recurrent Acute Colonic Diverticulitis: Meta-Analysis of Randomized, PlaceboControlled Trials. Am J Gastroenterol. 2016; 111(4): 579-81. PubMed Abstract | Publisher Full Text

126. Uno Y, van Velkinburgh JC: Logical hypothesis: Low FODMAP diet to prevent diverticulitis. World J Gastrointest Pharmacol Ther. 2016; 7(4): 503-12. PubMed Abstract | Publisher Full Text | Free Full Text 


\section{Open Peer Review}

\section{Current Peer Review Status:}

\section{Editorial Note on the Review Process}

Faculty Reviews are review articles written by the prestigious Members of Faculty Opinions. The articles are commissioned and peer reviewed before publication to ensure that the final, published version is comprehensive and accessible. The reviewers who approved the final version are listed with their names and affiliations.

\section{The reviewers who approved this article are:}

\section{Version 1}

\section{Angel Lanas}

Service of Gastroenterology, University Hospital, Zaragoza, 50009, Spain

Competing Interests: No competing interests were disclosed.

\section{Massimo Bellini}

Gastrointestinal Unit, Department of Gastroenterology, University of Pisa, Pisa, Italy

Competing Interests: No competing interests were disclosed.

\section{Andreas D Rink}

Department of General, Visceral and Thoracic Surgery, Leverkusen General Hospital, Leverkusen, Germany

Competing Interests: No competing interests were disclosed.

The benefits of publishing with F1000Research:

- Your article is published within days, with no editorial bias

- You can publish traditional articles, null/negative results, case reports, data notes and more

- The peer review process is transparent and collaborative

- Your article is indexed in PubMed after passing peer review

- Dedicated customer support at every stage

For pre-submission enquiries, contact research@f1000.com 